\title{
Three atropisomers of biphenyl: twist by tunable para substituents
}

\author{
RAMESH KARUPNASWAMY and PRABUSANKAR GANESAN* (D \\ Department of Chemistry, Indian Institute of Technology Hyderabad, Kandi, Sangareddy, Telangana 502 285, \\ India \\ E-mail: prabu@iith.ac.in
}

MS received 8 February 2018; revised 20 March 2018; accepted 20 March 2018; published online 30 June 2018

\begin{abstract}
The geometrical twist of aryl-aryl bond in biphenyl by weakly coordinating anion and selone at the para position has not been clear so far. We report here the synthesis and investigation into the diverse structural properties of biphenyl with weakly coordinating biphenyl imidazolium salts and neutral imidazole selone that exhibit three atropisomers of biphenyl. The approaches underline the diversity of the effects of para substituent with dynamic nature at biphenyl molecule.
\end{abstract}

Keywords. Biphenyl rotation; fluxional molecule; imidazole; selone.

\section{Introduction}

The tunable dihedral or twist angle $(\phi)$ of biphenyl derivatives have garnered long-standing attention due to their potential application in molecular electronics ${ }^{1-3}$ and catalytic transformations. ${ }^{4}$ As shown in Scheme 1, the biphenyl is known to exist from $45^{\circ}$ to $90^{\circ}$ twist angle in the gaseous state due to ortho substituent repulsion, ${ }^{5,6}$ while the biphenyl appears to be planar in the crystalline state at room temperature due to $\pi$-electron delocalization. ${ }^{7,8}$ It is clear that the controlled tunability of biphenyl ring by suitable substituent is paramount, ${ }^{9}$ as these characteristics are key to adapting the unique structural and electronic demands of materials. However, the ostensible structural inconsistency was observed with substituted biphenyl. Indeed the exhaustive survey was carried out by Grein et al., in 2002 to understand the relationship between twist angles and rotation energy barriers of biphenyl and substituted biphenyls using high-level Hartree-Fock and density functional calculations. ${ }^{10}$ Therefore, the steric factor plays a major role in the structures of mono substituted and meta disubstituted biphenyls. Whereas in the case of ortho dichloro biphenyl, the attractive force between two halogen atoms was considered.

\footnotetext{
*For correspondence
}

Later, the rotation at biphenyl with a single orthosubstituent was demonstrated by Mazzanti et al. ${ }^{11}$ Recently Masson et al., demonstrated the consequences of subtle changes to the biphenyl rotation. ${ }^{12}$ However, compared to ortho and meta substituted biphenyl derivatives, ${ }^{13}$ the net effect of para substituent on biphenyl ring is limited. ${ }^{14}$ As of our knowledge, the aryl-aryl twist in biphenyl mediated by tunable para substituent has not been documented. In order to gain further insight into the structural features of tunable para-substituted biphenyl species, we have examined the synthesis of 4,4'-substituted biphenyl and explored their structural diversity through anion exchange and selenation.

\section{Experimental}

\subsection{General consideration}

All manipulations were carried out under an argon atmosphere using Schlenk line techniques. The solvents were purchased from commercial sources and purified according to standard procedures. ${ }^{15} 4,4^{\prime}$-bis(chloromethyl)-1,1'-biphenyl, selenium powder, acetonitrile, toluene, methanol, and potassium carbonate were purchased from commercial sources. FT-IR measurements were carried out on a Bruker Alpha-P Fourier Transform spectrometer. NMR spectra were recorded on Bruker Ultra shield 400 spectrometers at $25^{\circ} \mathrm{C}$, unless otherwise stated. Chemical shifts are given relative to TMS and 


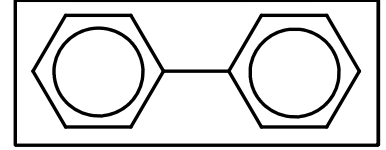

Crystalline State

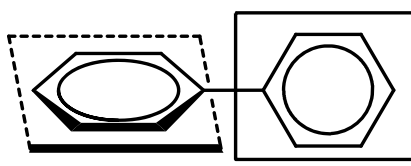

Gaseous State
Scheme 1. Structure of biphenyl. Crystalline state: $\phi=0^{\circ}$. Gaseous state: $\phi=45^{\circ}-90^{\circ}$.

were referenced to the solvent resonances as internal standards. Single crystals of $\mathbf{2}$ and $\mathbf{3}$ for the single crystal analysis were obtained from their saturated solutions in methanol, layered with hexane at room temperature, while $\mathbf{4}$ was obtained from its saturated solutions in chloroform, layered with hexane at room temperature. Suitable single crystals for X-ray structural analysis of 2-4 were mounted at room temperature in inert oil under liquid nitrogen condition. Using Olex $2,{ }^{16}$ the structure was solved with the ShelXS ${ }^{17,18}$ structure solution program using Direct Methods and refined with the olex2.refine refinement package using Gauss-Newton minimization. Absorption corrections were performed on the basis of multi-scans. Non-hydrogen atoms were anisotropically refined. No restraint has been made for any of the compounds. 2 depicted both "A level and B level alerts" due to a very high thermal parameter of isopropyl groups as well as disordered $\mathrm{BF}_{4}^{-}$ions. Attempts to resolve the alerts for $\mathbf{2}$ by alternative space group, $P_{2} / \mathrm{c}$ were not successful. $\mathbf{3}$ gave both "A level and B level alerts" due to a very high thermal parameter of isopropyl groups. A minor " $\mathrm{B}$ level alert in $\mathbf{4}$ that is associated with 'MainMol' Ueq as compared to neighbors of C11 is due to the thermal parameter differences between $\mathrm{C} 11$ and neighboring atom.

\subsection{Synthesis of 1}

Freshly prepared 1-isopropyl imidazole ( $2.3 \mathrm{~mL}, 49.8 \mathrm{mmol})$ was added to 4,4'-bis (chloromethyl)-1,1'-biphenyl (2.0 g, $19.9 \mathrm{mmol})$ in acetonitrile $(20 \mathrm{~mL})$ under argon atmosphere. The reaction mixture was refluxed for $48 \mathrm{~h}$ at $85^{\circ} \mathrm{C}$. The reaction progress was monitored by TLC. After completion of the reaction, the product $\mathbf{1}$ was formed as a white precipitate. Yield: $97 \%$ (based on 4,4'-bis(chloromethyl)-1,1biphenyl). M.p.: $108-110^{\circ} \mathrm{C}$. Elemental analysis calcd. (\%) for $\mathrm{C}_{26} \mathrm{H}_{32} \mathrm{~N}_{4} \mathrm{Cl}_{2}$ (471.47): C, 66.24; $\mathrm{H}, 6.84 ; \mathrm{N}, 11.88$; Found: $\mathrm{C}, 66.1 ; \mathrm{H}, 6.7 ; \mathrm{N}, 11.7 .{ }^{1} \mathrm{H}$ NMR $\left(\mathrm{D}_{2} \mathrm{O}, 400 \mathrm{MHZ}\right)$ : $\delta=7.56-7.54(\mathrm{~d}, 4 \mathrm{H}, \operatorname{Im} H), 7.38-7.34(\mathrm{~m}, 8 \mathrm{H}, \operatorname{Ar} H)$, 5.29(s, 4H, $\left.\mathrm{NCH}_{2}\right), 4.54-4.44\left(\mathrm{sept}, 1 \mathrm{H},{ }^{i} \mathrm{PrCH}\right), 1.40$ 1.39(d, $\left.12 \mathrm{H},{ }^{i} \mathrm{PrCH} \mathrm{H}_{3}\right) .{ }^{13} \mathrm{CNMR}\left(\mathrm{D}_{2} \mathrm{O}, 100 \mathrm{MHz}\right): \delta=143.08$ $(\mathrm{ImCH}), 136.13\left(\mathrm{ArCH}_{\mathrm{ipso}}\right), 131.96\left(\mathrm{ArCH}_{\mathrm{ortho}}\right), 130.42$ $\left(\mathrm{ArCH} \mathrm{H}_{\text {meta }}\right), 125(\mathrm{ImCH}), 123.61(\operatorname{ImCH}), 55.99\left({ }^{i} \mathrm{PrCH}\right)$, 55.17 $\left(\mathrm{NCH}_{2}\right), 24.67\left({ }^{i} \mathrm{PrCH} \mathrm{H}_{3}\right)$. FT-IR (neat): $\bar{v}=3426(\mathrm{w})$ 3366(w), 3120(w), 3047(s), 2971(w), 1617(w), 1557(s), 1543(m), 1502(m), 1461(m), 1415(m), 1331(m),1267(m), 1176(s), 1140(s), 854(s), 789(s), 748(s), 654(s), 611(s) $\mathrm{cm}^{-1}$.

\subsection{Synthesis of 2}

To a stirred solution of $\mathbf{1}(0.2 \mathrm{~g}, 0.4 \mathrm{mmol})$ in methanol $(3 \mathrm{~mL})$, ammonium tetrafluoroborate $(1.7 \mathrm{~g}, 1.1 \mathrm{mmol})$ was added, and the reaction mixture was stirred for $4 \mathrm{~h}$ at room temperature. After completion of the reaction, the mixture was evaporated under reduced pressure to get crude solid which was further washed with water $(25 \mathrm{~mL})$, and the solid was dissolved in methanol $(8 \mathrm{~mL})$ and dried over anhydrous sodium sulfate.The solvent was evaporated under reduced pressure to get analytically pure white solid 2 . Yield: $75 \%$ (based on 1). M.p.: $128-130{ }^{\circ} \mathrm{C}$. Elemental analysis calcd. (\%) for $\mathrm{C}_{26} \mathrm{H}_{32} \mathrm{~B}_{2} \mathrm{~N}_{4} \mathrm{~F}_{8}$ (574.17): C, 54.39; H, 5.62; N, 9.76; Found (\%): C, 54.4; H, 5.5; N, 9.7. ${ }^{1} \mathrm{H}$ NMR (DMSO- $d_{6}$, 400MHz): $\delta=9.41(\mathrm{~s}, 2 \mathrm{H}, \operatorname{Im} H), 7.94-7.86(\mathrm{~d}, 4 \mathrm{H}, \operatorname{Im} H)$, 7.76-7.74 (d, 4H, $\left.\operatorname{Ar} H_{\text {ortho }}\right), 7.56-7.54$ (d, 4H, ArH $H_{\text {meta }}$ ), 5.46 (s, $4 \mathrm{H}, \mathrm{NCH}_{2}$ ), 4.71-4.61 (sept, $1 \mathrm{H},{ }^{i} \mathrm{PrCH}$ ), 1.51 $1.49\left(\mathrm{~d}, 12 \mathrm{H},{ }^{i} \mathrm{PrCH} \mathrm{H}_{3}\right),{ }^{13} \mathrm{C}$ NMR (DMSO- $d_{6}, 100 \mathrm{MHz}$ ): $\delta=139.72(\operatorname{ImCH}), 134.97\left(\operatorname{ArC}_{\mathrm{ipso}}\right), 129\left(\mathrm{ArCH}_{\text {ortho }}\right)$, 134.22 ( $\left.\mathrm{ArCH}_{\text {meta }}\right), 121\left(\mathrm{Ar} C_{\text {para }}\right), 122.60(\mathrm{ImCH}), 127.28$ $(\mathrm{ImCH}), 52.40\left({ }^{i} \mathrm{PrCH}\right), 51.61\left(\mathrm{NCH}_{2}\right), 22.22\left({ }^{i} \mathrm{PrCH}_{3}\right) \cdot{ }^{11} \mathrm{~B}$ NMR (DMSO- $\left.d_{6}, 128.4 \mathrm{MHz}\right): \delta=1.25\left(\mathrm{~s}, B \mathrm{~F}_{4}^{-}\right) .{ }^{19} \mathrm{~F} \mathrm{NMR}$ (DMSO- $\left.d_{6}, 376.4 \mathrm{MHz}\right): \delta=148.18\left(\mathrm{~s}, \mathrm{~B} F_{4}^{-}\right)$. FT-IR (neat): $\bar{v}$ $=3155(\mathrm{~m}), 1624(\mathrm{w}), 1558(\mathrm{~m}), 1449(\mathrm{~m}), 1157(\mathrm{w}), 1031(\mathrm{~s})$, 863(w), 831(m), 762(w), 746(m), 699(m), 655(m), 611(w) $\mathrm{cm}^{-1}$.

\subsection{Synthesis of 3}

To $1(0.2 \mathrm{~g}, 0.4 \mathrm{mmol})$ in water $(3 \mathrm{~mL}), \mathrm{KPF}_{6}(0.2 \mathrm{~g}, 1.3$ $\mathrm{mmol})$ in water $(3 \mathrm{~mL})$ was added under stirring condition. A white precipitate was formed immediately and refluxed for 5 $\mathrm{h}$ to afford white precipitate in good yield. The precipitate was filtered and washed with methanol. This was further dissolved in acetone, dried over sodium sulfate, filtered and the solvent was evaporated under reduced pressure to afford an analytical pure compound 3. Yield: $86 \%$ (based on 1). M.p.: 140 $142{ }^{\circ} \mathrm{C}$. Elemental analysis calcd. (\%) for $\mathrm{C}_{26} \mathrm{H}_{32} \mathrm{~N}_{4} \mathrm{~F}_{12} \mathrm{P}_{2}$ (690.49): C, 45.23; H, 4.67; N, 8.11; Found (\%): C, 45.2; $\mathrm{H}, 4.6 ; \mathrm{N}, 8.1 .{ }^{1} \mathrm{H}$ NMR (DMSO- $d_{6}, 400 \mathrm{MHz}$ ): $\delta=9.41$ (s, 2H, $\operatorname{Im} H), 7.93-7.86(\mathrm{~d}, 4 \mathrm{H}, \operatorname{Im} H), 7.77-7.75(\mathrm{~d}, 4 \mathrm{H}$, $\operatorname{Ar} H_{\text {ortho }}$ ), 7.56-7.54 (d, $\left.4 \mathrm{H}, \operatorname{Ar} H_{\text {meta }}\right), 5.46$ (s, 4H, NCH$H_{2}$ ), 4.71-4.62 (m, $\left.1 \mathrm{H},{ }^{i} \mathrm{PrCH}\right), 1.52-1.50\left(\mathrm{~d}, 12 \mathrm{H},{ }^{i} \mathrm{PrCH}_{3}\right) .{ }^{13} \mathrm{C}$ NMR (DMSO- $\left.d_{6}, 100 \mathrm{MHz}\right): \delta=139.74(\operatorname{ImCH}), 134.97$ $\left(\mathrm{Ar} C_{\mathrm{ipso}}\right), 128.98\left(\mathrm{ArC} \mathrm{H}_{\mathrm{ortho}}\right), 127.29\left(\mathrm{ArCH} \mathrm{H}_{\text {meta }}\right), 134.19$ $\left(\mathrm{Ar} C_{\text {para }}\right), 120.99(\mathrm{ImCH}), 122.60(\mathrm{ImCH}), 52.41\left({ }^{i} \mathrm{PrCH}\right)$, $51.64\left(\mathrm{NCH}_{2}\right), 22.19\left({ }^{i} \mathrm{PrCH} \mathrm{H}_{3}\right) .{ }^{31} \mathrm{P}$ NMR (DMSO- $d_{6}, 161$ MHz): $\delta=157.33-130.98\left(\right.$ septet, $\left.P \mathrm{~F}_{6}^{-}\right) .{ }^{19} \mathrm{~F}$ NMR (DMSO$\left.d_{6}, 161 \mathrm{MHz}\right): \delta=71.03-69.14\left(\mathrm{~d}, \mathrm{P} F_{6}^{-}\right)$. FT-IR (neat): $\bar{v}$ $=3156(\mathrm{w}), 1555(\mathrm{~m}), 1175(\mathrm{w}), 1145(\mathrm{~m}), 829(\mathrm{~s}), 751(\mathrm{~m})$, $655(\mathrm{~m}), 556(\mathrm{~m}) \mathrm{cm}^{-1}$.

\subsection{Synthesis of 4}

$\mathbf{1}$ or $\mathbf{2}$ or $\mathbf{3}$ ( $4.3 \mathrm{mmol}$ ), activated potassium carbonate (1.8 $\mathrm{g}, 12.8 \mathrm{mmol})$, Se powder $(0.4 \mathrm{~g}, 5 \mathrm{mmol})$, and methanol $(25 \mathrm{~mL})$ were added under argon atmosphere. The reaction 

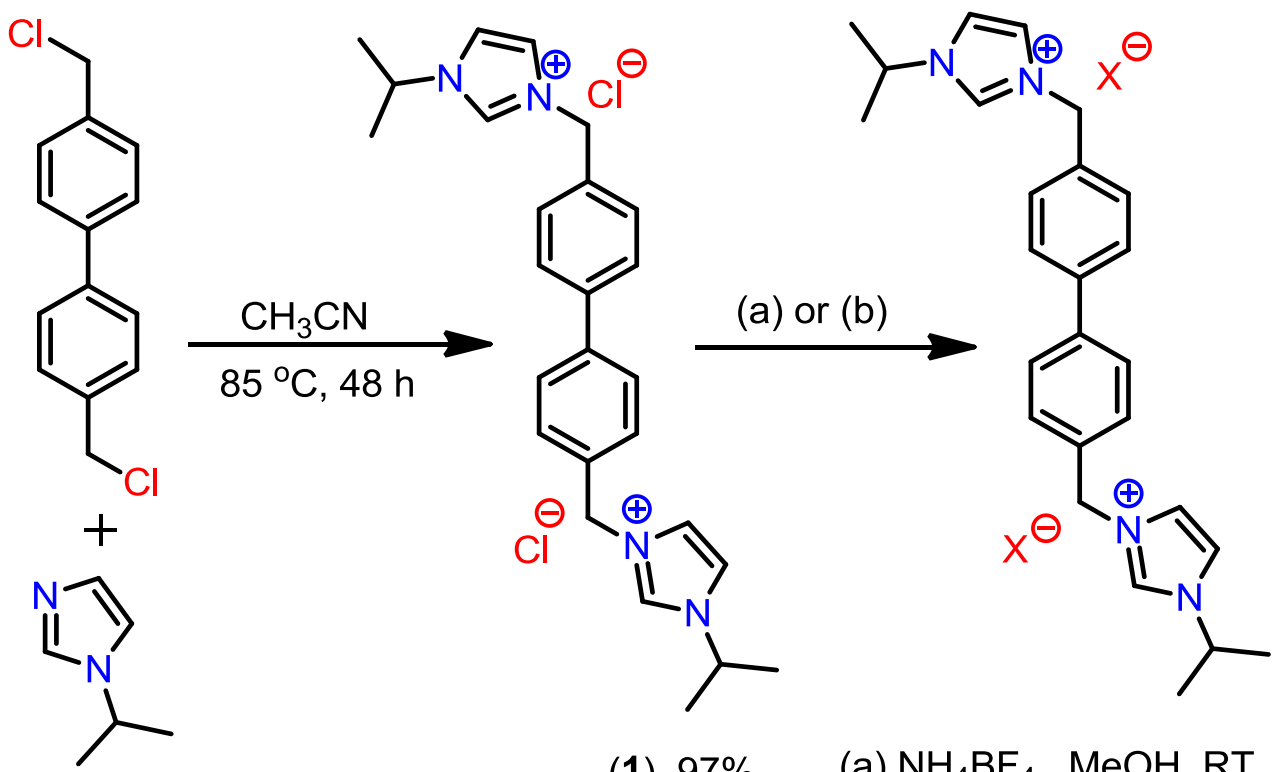

(1), $97 \%$

(a) $\mathrm{NH}_{4} \mathrm{BF}_{4}, \mathrm{MeOH}, \mathrm{RT}, 5 \mathrm{~h}$;

$\mathrm{X}=\mathrm{BF}_{4}^{-}, 75 \%(2)$

(b) $\mathrm{KPF}_{6}, \mathrm{H}_{2} \mathrm{O}, \mathrm{RT}, 4 \mathrm{~h}$;

$\mathrm{X}=\mathrm{PF}_{6}^{-}, 86 \%(3)$
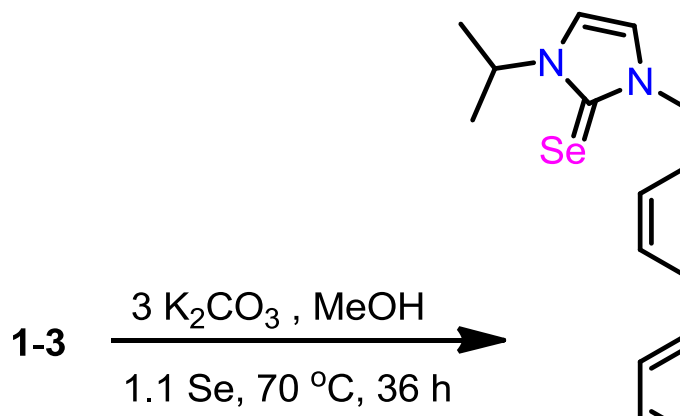

(4), $56-62 \%$

$1.1 \mathrm{Se}, 70^{\circ} \mathrm{C}, 36 \mathrm{~h}$

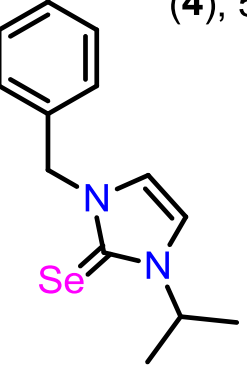

Scheme 2. Synthesis of 1-4.

mixture was refluxed for $36 \mathrm{~h}$ at $70^{\circ} \mathrm{C}$. The progress of the reaction was monitored by TLC. After completion of the reaction, water was added to the reaction mixture and extracted with dichloromethane $(3 \times 15 \mathrm{~mL})$. The organic extract was washed with $\mathrm{Na}_{2} \mathrm{SO}_{4}$ and evaporated under reduced pressure. Yield: $56-62 \%$ (based on 1 or 2 or 3). M.p.: $198-200{ }^{\circ} \mathrm{C}$. Elemental analysis calcd. (\%) for $\mathrm{C}_{26} \mathrm{H}_{30} \mathrm{~N}_{4} \mathrm{Se}_{2}$ (556.46): $\mathrm{C}$, 56.12; H, 5.43; N, 10.07; Found (\%): C, 56.0; H, 5.3; N, 10.0. ${ }^{1} \mathrm{H} \mathrm{NMR}\left(\mathrm{CDCl}_{3}, 400 \mathrm{MHz}\right): \delta=7.54-7.52\left(\mathrm{~d}, 4 \mathrm{H}, \mathrm{Ar} H_{\mathrm{ortho}}\right)$, 7.41-7.39 (d, 4H, Ar $\left.H_{\text {meta }}\right), 6.95$ (d, 2H, Im H), 6.86 (d, 2H, $\operatorname{Im} H$ ), 5.42 (s, 4H, $\mathrm{NCH}_{2}$ ), 5.29-5.21 (sept, $2 \mathrm{H},{ }^{i} \mathrm{PrCH}$ ), 1.41-1.40 (d, $\left.12 \mathrm{H},{ }^{i} \mathrm{PrCH}_{3}\right) .{ }^{13} \mathrm{C} \mathrm{NMR}\left(\mathrm{CDCl}_{3}, 100 \mathrm{MHz}\right)$ : $\delta=154.94(\mathrm{C}=\mathrm{Se}), 119.02(\mathrm{ImCH}), 115.53(\mathrm{ImCH}), 140.27$
$\left(\mathrm{ArC}_{\mathrm{ipso}}\right), 128.84\left(\mathrm{ArCH}_{\text {ortho }}\right), 127.42\left(\mathrm{ArCH}_{\text {meta }}\right), 134.89$ $($ ArC $\mathrm{para}), 52.26\left({ }^{i} \mathrm{PrCH}\right), 51.20\left(\mathrm{NCH}_{2}\right), 22\left({ }^{i} \mathrm{PrCH}_{3}\right)$. FT-IR (neat): $\bar{v}=3080(\mathrm{w}), 2974(\mathrm{w}), 1990(\mathrm{w}), 1662(\mathrm{~m}), 1562(\mathrm{~m})$, 1499(m), 1452(m), 1423(m), 1398(vs), 1363(m), 1287(w), 1220(s), 1186(m), 1133(w), 1043(m), 747(s), 670(m) cm $\mathrm{cm}^{-1}$.

\section{Results and Discussion}

\subsection{Synthesis and characterization of 1-4}

The water-soluble and hygroscopic salt $\mathbf{1}$ was obtained in excellent yield by treating freshly prepared 
1-isopropyl imidazole with 4,4'-bis (chloromethyl)-1, 1'-biphenyl in acetonitrile (Scheme 2). The counter ion chloride was conveniently exchanged by tetrafluoroborate or hexafluorophosphate to yield $\mathbf{2}$ and $\mathbf{3}$, respectively (Scheme 2). 1-3 are soluble in highly polar solvents like DMSO, $\mathrm{MeOH}$ and water. The salts 1-3 were characterized by $\mathrm{CHN}$ analysis, FTIR, ${ }^{1} \mathrm{H}$ NMR and ${ }^{13} \mathrm{C}$ NMR techniques. In ${ }^{1} \mathrm{H}$ NMR, the imidazolium $C \mathrm{H}$ peak in $\mathbf{2}$ and $\mathbf{3}$ appeared at $\delta 9.41$, while it is absent for $\mathbf{1}$ due to proton exchange by deuterium. In addition, the tetrafluoroborate salt (2) and hexafluorophosphate salt (3) were further confirmed by ${ }^{19} \mathrm{~F}$ NMR, ${ }^{31} \mathrm{P}$ NMR and ${ }^{11} \mathrm{~B}$ NMR spectroscopy. The ${ }^{11} \mathrm{~B}$ NMR spectrum of 2 showed a sharp signal in the range of $\delta 1.25$ and ${ }^{19} \mathrm{~F}$ NMR spectra of 2 showed a sharp signal at $\delta 148.18$. The ${ }^{31} \mathrm{P}$ NMR spectrum of $\mathbf{3}$ depicted a septet in the range of $\delta$ 157.33-130.98 and ${ }^{19} \mathrm{~F}$ NMR spectra of 3 gave doublet at $\delta 71.03-69.14$.

The selone 4 was isolated in good yield from the reaction between $\mathbf{1}$ or $\mathbf{2}$ or $\mathbf{3}$, and 1.1 equivalences of Se in the presence of six equivalences potassium carbonate (Scheme 2). The formation of $\mathbf{4}$ was confirmed by FT-IR, elemental analysis and multinuclear NMR $\left({ }^{1} \mathrm{H}\right.$, and ${ }^{13} \mathrm{C}$ ). The FT-IR spectrum of $\mathbf{4}$ depicts the $\mathrm{C}=\mathrm{Se}$ bond stretching frequency at $1220 \mathrm{~cm}^{-1}$. In ${ }^{1} \mathrm{H}$ NMR, the $\mathrm{CH}-\mathrm{CH}$ - protons of the imidazole rings in $\mathbf{4}$ are $(\delta$ 6.95 and 6.86) significantly upfield shifted compared to that of corresponding imidazolium salts $(\delta 7.56-7.54$ for $1, \delta 7.94-7.86$ for 2 and $\delta 7.93-7.86$ for 3 ). In ${ }^{13} \mathrm{C}$ NMR, the $\mathrm{N}-C(\mathrm{Se})-\mathrm{N}$ carbon in $\mathbf{4}$ is $(\delta 154.94)$ about $\delta$ 12-15 shifted downfield compared with N-CH-N carbon in 1-3 ( $\delta 143.08$ for $\mathbf{1}, \delta 139.72$ for $\mathbf{2}$ and $\delta 139.74$ for 3 ). Besides, $C=$ Se carbon chemical shift value of $\mathbf{4}$ is upfield shifted $(\delta 7)$ from those of the corresponding ligand $\operatorname{IPr}=\operatorname{Se}(\delta$ 162.2 $),{ }^{19}$ due to a decrease in the $\pi$ acceptance nature of $\mathbf{4}$. The DEPT spectrum of $\mathbf{4}$ depicts the existence of $\mathrm{CH}_{2}, \mathrm{CH}_{3}$ and $\mathrm{CH}$ groups that are in accordance with the structure of $\mathbf{4}$.

\subsection{Solid state structure of 2-4}

The solid-state structures of $\mathbf{2 - 4}$ were unambiguously determined by single crystal X-ray diffraction technique. 2-4 crystallized in monoclinic space group, $P c$ for $\mathbf{2}, P 2_{1} / c$ for $\mathbf{3}$ and $\mathbf{4}$. The solid-state structures of 2-4 are shown in Figure 1 along with selected bond distances and bond angles. $\mathbf{2}$ and $\mathbf{3}$ are ionic salts, while $\mathbf{4}$ is a neutral molecule. The imidazolium charges in $\mathbf{2}$ are balanced by two tetrafluoroborate anions, while two hexafluorophosphate ions are balancing out the imidazolium charges in 3 . Notably, the orientation of biphenyl group and five-membered $\mathrm{N}$-heterocyclic moieties in 2-4 are not comparable. The N-C bond distances of

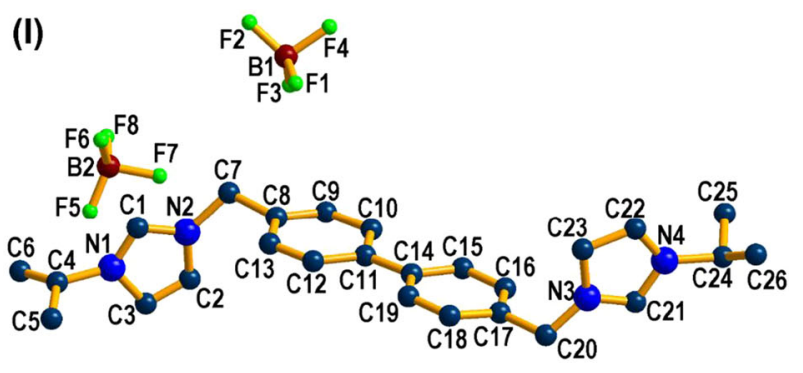

(II)
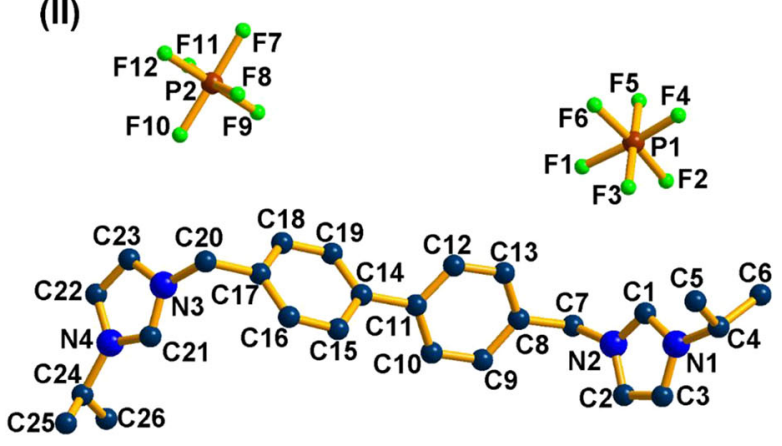

(III)

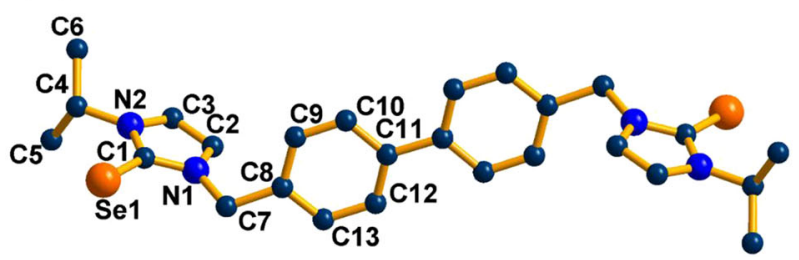

Figure 1. Solid state structures of 2-4. Selected bond distances $[\AA]$ and angles $\left[{ }^{\circ}\right]$ : for 2 : $\mathrm{C}(1)-\mathrm{N}(1), 1.250(12)$; $\mathrm{C}(1)-\mathrm{N}(2), 1.310(10) ; \mathrm{N}(3)-\mathrm{C}(21), 1.305(10) ; \mathrm{N}(4)-\mathrm{C}(21)$, 1.312(11); ( $\mathrm{N}(2)-\mathrm{C}(1)-\mathrm{N}(2), 110.1(9)$ and $\mathrm{N}(4)-\mathrm{C}(21)-\mathrm{N}(3)$, 112.1(9) for 3: $\mathrm{C}(1)-\mathrm{N}(1), 1.342(7) ; \mathrm{C}(1)-\mathrm{N}(2), 1.312(6)$; $\mathrm{N}(4)-\mathrm{C}(21), 1.328(7) ; \mathrm{N}(3)-\mathrm{C}(21), 1.329(7) ; \mathrm{N}(2)-\mathrm{C}(1)-\mathrm{N}(1)$, 108.2(5) and $\mathrm{N}(4)-\mathrm{C}(21)-\mathrm{N}(3), 109.1(5)$. For 4: $\mathrm{C}(1)-\mathrm{N}(1)$, $1.363(5) ; \quad \mathrm{C}(1)-\mathrm{N}(2), \quad 1.354(5) ; \quad \mathrm{C}(1)-\mathrm{Se}(1), \quad 1.825(4) ;$ $\mathrm{N}(2)-\mathrm{C}(1)-\mathrm{N}(1), 105.0(4)$.

$\mathrm{N}-\mathrm{C}-\mathrm{N}$ are not comparable. Within $\mathbf{2}$ and $\mathbf{3}$, the N-C bond distances are not comparable, while the $\mathrm{N}-\mathrm{C}$ bond distances are equal in $\mathbf{4}$. This can be attributed to the good $\pi$ overlap between $\mathrm{N}-\mathrm{C}(\mathrm{Se})-\mathrm{N}$. Besides, a gradual increase in the $\mathrm{N}-\mathrm{C}$ bond distances is observed from 2, 3 to 4 . The $\mathrm{N}-\mathrm{C}-\mathrm{N}$ bond angles in $\mathbf{2}$ are slightly wider than that of $\mathbf{3}$. Upon selenation, a considerable decrease in the N-C-N bond angle was observed for $\mathbf{4}$ compared to $\mathbf{2}$ and $\mathbf{3}$. The $\mathrm{C}=\mathrm{Se}$ bond distance in $\mathbf{4}$ is $1.825(4) \AA$, which is comparable with that of $\mathrm{IPr}=\mathrm{Se}$ $(1.853 \AA),{ }^{20} 4,4^{\prime}$-bis(N,N'-methyl imidazole-2-selone)1,1'-biphenyl (C=Se, $1.874 \AA$ ), and 4,4'-bis(N,-methyl$\mathrm{N}^{\prime}$-allyl imidazole-2-selone)-1,1'-biphenyl $(\mathrm{C}=\mathrm{Se}$, $1.850 \AA) .{ }^{21}$ 


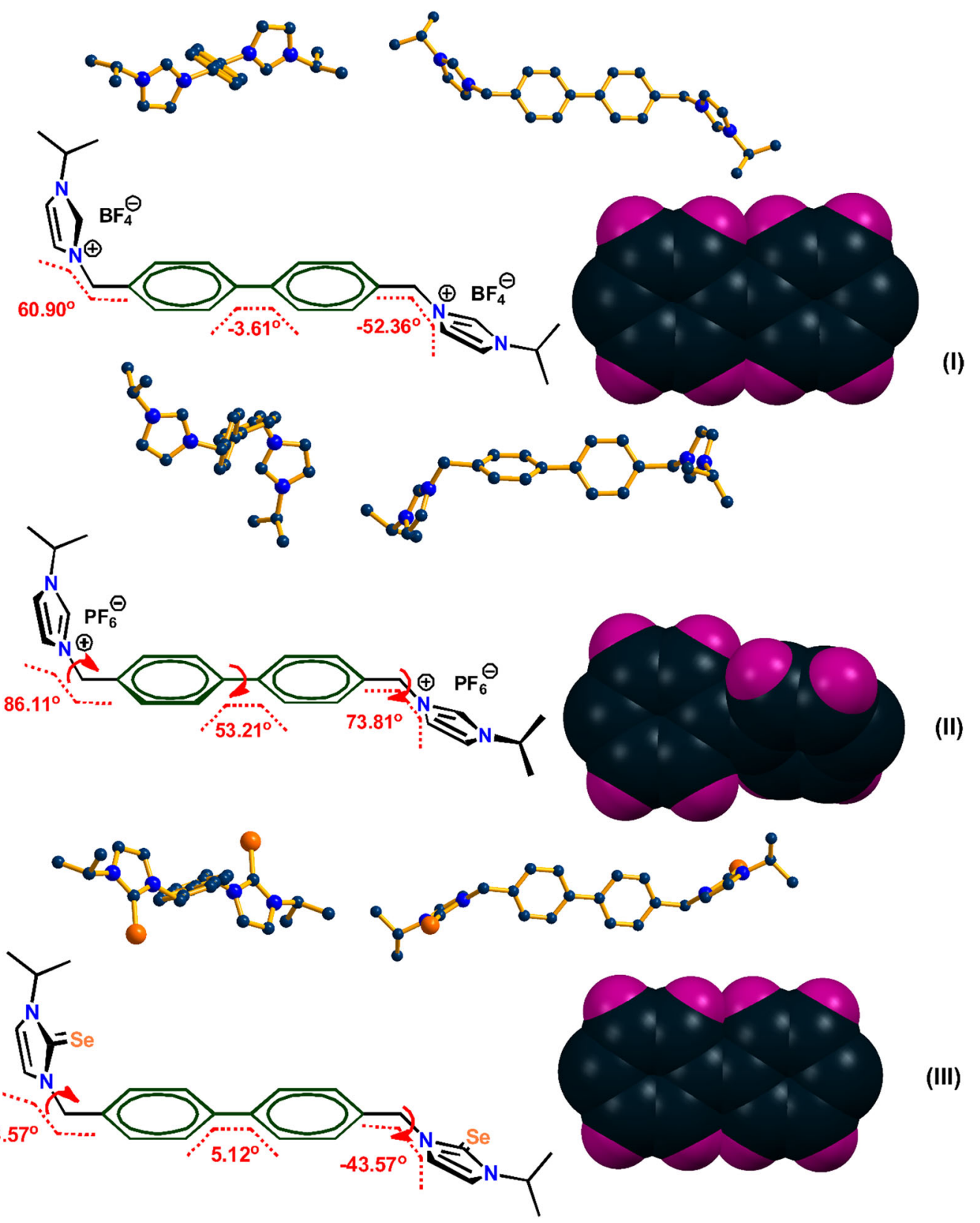

Figure 2. The atropisomers of phenyl and geometrical orientation of N-heterocyclic rings in 2-4.

\subsection{Geometrical orientation of 2-4}

As shown in Figure 2, the geometrical orientation of phenyl and $\mathrm{N}$-heterocyclic rings are different in $\mathbf{2}$ 4. In 2 and 4, the phenyl rings are nearly on the same plane, while two N-heterocyclic rings are in trans position. Interestingly, the geometrical orientation of phenyl rings in $\mathbf{3}$ is considerably twisted to each other and imidazolium rings are in trans orientation. Interestingly, the biphenyl twist angle of $\mathbf{3}$ is nearly comparable with that of 2,2'-difluoro biphenyl $\left(57.6^{\circ}\right){ }^{22}$ Thus, the torsion angles between phenyl rings in $\mathbf{2 - 4}$ are not comparable $\left(-3.61^{\circ}\right.$ for $\mathbf{2}, 53.21^{\circ}$ for 3 and $5.12^{\circ}$ for 4). Interestingly, the biphenyl twist angle observed in 4 is considerably wider than that of 4,4'-bis(N, $\mathrm{N}^{\prime}$-methyl imidazole-2-selone)-1, $1^{\prime}$ biphenyl $\left(-0.47^{\circ}\right), \quad$ and $4,4^{\prime}$-bis $\left(\mathrm{N},-\right.$ methyl- $\mathrm{N}^{\prime}$ allyl imidazole-2-selone)-1, $1^{\prime}$-biphenyl $\left(2.99^{\circ}\right) .{ }^{21} \mathrm{Sim}$ ilarly, the torsion angles between the phenyl and $\mathrm{N}$ heterocyclic ring are distinctly different $\left(60.90^{\circ}\right.$ and $-52.36^{\circ}$ for $2 ; 86.11^{\circ}$ and $73.81^{\circ}$ for $3 ; 43.57^{\circ}$ and $-43.57^{\circ}$ for 4$)$. Therefore, the molecular packing of 2-4 is quite exciting. $\mathbf{2}$ and $\mathbf{3}$ are arranged in a three-dimensional network with extensive F....H hydrogen bonding interaction between weakly coordinating anion and imidazolium moiety. Besides, the molecular 
orientation and hydrogen bonding interactions were further confirmed on the basis of 2D (HSQC and HMBC) NMR experiments (See Supporting Information).

\section{Conclusions}

In summary, we have synthesized and characterized the biphenyl with ionic imidazolium salts and neutral imidazole selone at para position. The structural properties of biphenyl with weakly coordinating biphenyl imidazolium salts and neutral imidazole selone have been demonstrated to exhibit three atropisomers of biphenyl in the solid state, unique to that of the para-substituted diphenyl analogues. The minor twist at biphenyl moiety gave notable changes in the solid packing of ionic imidazolium salts and neutral imidazole selone molecule. Similarly, the increase in the bulkiness at $\mathrm{N}$-substituent from methyl to allyl and isopropyl at imidazole selone depicted a notable twist at biphenyl ring. However, the results indicate that substantial work remains to be accomplished in order to translate our understanding of corresponding carbene metal and chalcogenone metal derivatives for stereoselective catalytic reactions. This is the subject of ongoing investigations in our group.

\section{Supplementary Information (SI)}

FT-IR, NMR spectra and packing diagram are available at www.ias.ac.in/chemsci. CCDC 1822980-1822982 contain the supplementary crystallographic data for this paper. These data can be obtained free of charge from the Cambridge Crystallographic Data Centre via www.ccdc.cam.ac.uk/data request/cif or from the Cambridge Crystallographic Data Centre, 12 Union Road, Cambridge CB2 1EZ, UK; fax: +44 1223336 033; or e-mail: deposit@ccdc.cam.ac.uk.

\section{Acknowledgements}

We gratefully acknowledge the CSIR, New Delhi (01(2884)/ 17/EMR-II) for financial support. RK thanks UGC for the fellowship.

\section{References}

1. Kudernac T, Ruangsupapichat N, Parschau M, Maciá B, Katsonis N, Harutyunyan S R, Ernst K and Feringa B L 2011 Electrically driven directional motion of a fourwheeled molecule on a metal surface Nature 479208

2. Chuhmanov E P, Ermolaev N L, Plakhutin B N and Ignatov S K 2018 Tris(perfluoroalkyl)germylethynyl derivatives of biphenyl containing ferrocenyl donor group: Structure, spectra, and photoinduced intramolecular electron transfer comput Theor. Chem. 112350

3. Maier F and Trapp O 2013 The stereodynamics of 5,5'disubstituted BIPHEPs Chirality 25126
4. Fischer F, Siegle A F, Checinski M, Fischer C, Kral K, Thede R, Trapp O and Hapke M 2016 Synthesis of naphthylpyridines from unsymmetrical naphthylheptadiynes and the configurational stability of the biaryl axis J. Org. Chem. 813087

5. Bastiansen O and Samdal S 1985 Structure and barrier of internal rotation of biphenyl derivatives in the gaseous state: Part 4. Barrier of internal rotation in biphenyl, perdeuterated biphenyl and seven non-ortho-substituted halogen derivatives J. Mol. Struct. 128115

6. Almenningen A, Bastiansen O, Fernholt L, Cyvin B N, Cyvin S J and Samdal S 1985 Structure and barrier of internal rotation of biphenyl derivatives in the gaseous state: Part 1. The molecular structure and normal coordinate analysis of normal biphenyl and pedeuterated biphenyl J. Mol. Struct. 12859

7. Charbonneau G P and Delugeard Y 1976 Structural transition in polyphenyls. III. Crystal structure of biphenyl at $110 \mathrm{~K}$ Acta Crystallogr. B32 1420

8. Cailleau H, Girard A, Moussa F and Zeyen C M E 1979 Inelastic neutron scattering study of structural phase transitions in polyphenyls Solid State Commun. 29259

9. Barton D H R 1970 The principles of conformational analysis Science 169539

10. Grein F 2002 Twist angles and rotational energy barriers of biphenyl and substituted biphenyls J. Phys. Chem. A 1063823

11. Mazzanti A, Lunazzi L, Minzoni $M$ and Anderson J E 2006 Rotation in biphenyls with a single orthosubstituent J. Org. Chem. 715474

12. Masson E 2013 Torsional barriers of substituted biphenyls calculated using density functional theory: a benchmarking study Org. Biomol. Chem. 112859

13. Lorentzen M, Kalvet I, Sauriol F, Rantanen T, Jørgensen K B and Snieckus V 2017 Atropisomerism in tertiary biaryl 2-amides: A study of $\mathrm{Ar}-\mathrm{CO}$ and $\mathrm{Ar}-\mathrm{Ar}$ ' rotational barriers J. Org. Chem. 827300

14. Bihlmeier A, Rotzler J, Rickhaus M, Mayor M and Klopper W 2015 Activation enthalpies and entropies of the atropisomerization of substituted butyl-bridged biphenyls Phys. Chem. Chem. Phys. 17 11165

15. Perrin D D and Armarego W L F 1988 In Purification of laboratory chemicals $3^{\mathrm{rd}}$ edn. (London: Pergamon Press)

16. Dolomanov O V, Bourhis L J, Gildea R J, Howard J A K and Puschmann H 2009 OLEX2: a complete structure solution, refinement and analysis program J. Appl. Cryst. 42339

17. Burla M C, Caliandro R, Camalli M, Carrozzini B, Cascarano G L, De Caro L, Giacovazzo C, Polidori G, Siliqi D and Spagna R 2007 IL MILIONE: a suite of computer programs for crystal structure solution of proteins J. Appl. Cryst. 40609

18. Bourhis L J, Dolomanov O V, Gildea R J, Howard J A K and Puschmann H 2015 The anatomy of a comprehensive constrained, restrained refinement program for the modern computing environment-Olex2 Dissected Acta Cryst. A71 59

19. Nelson D J, Collado A, Manzini S, Meiries S, Slawin, A M Z, Cordes D B and Nolan S P 2014 Methoxy-functionalized N-heterocyclic carbenes Organometallics $\mathbf{3 3} 2048$ 
20. (a) Tretiakov M, Shermolovich Y G, Singh A P, Samuel P P, Roesky H W, Niepötter B, Visschera A and Stalke D 2013 Lewis-base stabilized diiodine adducts with $N$-heterocyclic chalcogenamides Dalton Trans. 42 12940; (b) Nelson D J, Collado A, Manzini S, Meiries S, Slawin A M Z, Cordes D B and Nolan S P Methoxy-Functionalized $N$-Heterocyclic Carbenes Organometallics 332048 ; (c) Srinivas K, Suresh P, Babu C N, Sathyanarayana A and Prabusankar G 2015 Heavier chalcogenone complexes of bismuth(III)trihalides:
Potential catalysts for acylative cleavage of cyclic ethers RSC Adv. 515579

21. Sathyanarayana A, Srinivas K, Mandal A, Gharami S and Prabusankar G 2014 Synthesis, spectral and structural properties of bis-imidazole selones J. Chem. Sci. 126 1589

22. Aldridge B, De Luca G, Edgar M, Emsley J W, Furby M I C and Webster M 1998 The structure of 2,2' difluorobiphenyl in solid crystalline and liquid crystalline phases Liq. Cryst. 24569 